\title{
HUBUNGAN KONSUMSI ALKOHOL DENGAN GANGGUAN FUNGSI HATI PADA SUBJEK PRIA DEWASA MUDA DI KELURAHAN TATELI DAN TELING ATAS MANADO
}

\author{
${ }^{1}$ Dicky Conreng \\ ${ }^{2}$ B. J. Waleleng \\ ${ }^{2}$ Stella Palar \\ ${ }^{1}$ Kandidat Skripsi Fakultas Kedokteran Universitas Sam Ratulangi \\ ${ }^{2}$ Bagian Ilmu Penyakit Dalam Fakultas Kedokteran Universitas Sam Ratulangi \\ Email: Dickyconreng10_078@yahoo.com
}

\begin{abstract}
Alcohol consumption is the third biggest risk factor as a cause of disease and disability in the world, and is the biggest risk factor in America and second biggest in Europe as the cause of disease and disability. Alcohol is a causalfactorin 60 types of diseases and injuries and a component cause in 200 others. There are many diseases that is caused by alcohol consumption, one of them causes impaired liver function, such as alcoholic liver disease. However according to the theory, not all alcoholics will have an impaired liver function, so this reasearch was done to confirm that theory. Alcoholism will be measured by the AUDIT questionnaire and the impaired liver function will be measured by the increase in the GGT enzyme. Conclusion: Not all chronic alcoholics will have impaired liver function with the same amount of alcohol consumption.
\end{abstract}

Keywords: alcohol, impaired liver function, alcoholic liver disease, AUDIT, GGT.

\begin{abstract}
Abstrak: Konsumsi alkohol merupakan faktor risiko terbesar ketiga di dunia sebagai penyebab penyakit dan disabilitas, dan merupakan faktor risiko terbesar pertama di Amerika serta faktor risiko terbesar kedua di Eropa sebagai penyebab penyakit dan disabilitas. Alkohol merupakan faktor penyebab dari sekitar 60 jenis penyakit dan merupakan faktor komponen dari 200 jenis penyakit lainnya. Terdapat berbagai jenis penyakit yang disebabkan oleh konsumsi alkohol, salah satunya adalah gangguan fungsi hati seperti penyakit hati alkoholik (alcoholic liver disease). Namun menurut teori tidak semua peminum alkohol akan mengalami gangguan fungsi hati, sehingga penelitian ini dilakukan untuk memastikan teori tersebut. Gangguan konsumsi alkohol akan diperiksa menggunakan kuesioner AUDIT dan gangguan fungsi hati akan diperiksa melalui peningkatan enzim GGT. Simpulan: Tidak semua peminum alkohol kronik akan mengalami gangguan fungsi hati dengan jumlah konsumsi alkohol yang sama.
\end{abstract}

Kata kunci: alkohol, gangguan fungsi hati, penyakit hati alkoholik, AUDIT, GGT.

Konsumsi alkohol merupakan faktor risiko terbesar ketiga di dunia sebagai penyebab penyakit dan disabilitas, dan merupakan faktor risiko terbesar pertama di Amerika serta faktor risiko terbesar kedua di Eropa sebagai penyebab penyakit dan disabilitas. ${ }^{1,2}$ Alkohol merupakan faktor penyebab dari sekitar 60 jenis penyakit dan merupakan faktor komponen dari 200 jenis penyakit lainnya. ${ }^{1}$
Perkiraan angka kematian akibat konsumsi alkohol di dunia adalah sekitar 2.500.000 orang setiap tahun. ${ }^{1}$ Angka kematian pemuda usia 15-29 tahun di dunia akibat alkohol adalah sekitar 320.000 orang, 9\% dari total kematian pada kelompok usia tersebut. $^{2}$ Angka kematian akibat konsumsi alkohol di Indonesia adalah sekitar 50 orang per hari atau sekitar 18.000 orang per tahun. ${ }^{3}$ 
Terdapat berbagai jenis penyakit yang disebabkan oleh konsumsi alkohol, salah satunya adalah gangguan fungsi hati seperti penyakit hati alkoholik (alcoholic liver disease). Penyakit hati alkoholik (PHA) adalah gangguan fungsi hati yang diakibatkan oleh konsumsi alkohol dalam waktu yang lama dengan jumlah tertentu. Penyakit hati alkoholik terbagi atas perlemakan hati (fatty liver), hepatitis alkoholik (alcoholic hepatitis) dansirosis (cirrhosis). Perlemakan hati biasa ditemukan pada $>90 \%$ peminum alkohol rekuren dan berat. Dari sebagian peminum alkohol berat tersebut, sekitar 10-30\% akan berkembang menjadi penderita hepatitis alkoholik, dan akan terus berkembang menjadi sirosis bila tidak ada intervensi. ${ }^{4}$

Prognosis dari PHA berat buruk, dimana angka mortalitas pasien sirosis dalam 4 tahun hampir mencapai $60 \% .{ }^{4}$ Angka kematian akibat PHA di Amerika Serikat adalah sekitar 15,990 orang pada tahun 2010. ${ }^{5}$ Masalah tersebutlah yang mendorong penulis untuk melakukan penelitian mengenai hubungan konsumsi alkohol dan risiko terjadinya PHA.

\section{METODE PENELITIAN}

Penelitian yang dilakukan bersifat deskriptif prospektif berdasarkan data primer hasil pengisian kuesioner AUDIT dan pemeriksaan peningkatan GGT.
Penelitian ini dilakukan dari bulan November sampai Desember 2013. Sampel dalam penelitian ini adalah pria dewasa muda di Kelurahan Tateli dan Teling Atas yang memenuhi kriteria inklusi, yaitu usia 21-40 tahun, riwayat konsumsi alkohol dalam 1 tahun terakhir, skor AUDIT $\geq 8$ dan bersedia menjadi sampel penelitian.

\section{HASIL PENELITIAN}

Pada lokasi sampel pertama, yaitu pada daerah kelurahan Tateli, diambil 22 sampel. Dari 22 sampel yang diambil, 8 orang (36,36\%) orang memiliki nilai GGT yang tinggi dan 14 orang sisanya (62,64\%) memiliki nilai GGT yang normal.

Pada lokasi sampel kedua, yaitu pada daerah Kelurahan Teling Atas, diambil 8 sampel. Dari 8 sampel yang diambil, 2 orang (25\%) memiliki nilai GGT yang tinggi dan 6 orang sisanya (75\%) memiliki nilai GGT yang normal.

Jadi, dari 30 sampel yang diambil, 10 orang (33,33\%) memiliki nilai GGT yang tinggi dan 20 orang sisanya (66,67\%) memiliki nilai GGT yang normal. Namun beberapa dari 20 orang yang memiliki nilai GGT normal tersebut memiliki skor AUDIT yang mendekati, bahkan melebihi nilai ratarata skor AUDIT 10 orang yang memilikinilai GGT tinggi.

Tabel 1. Hasil pemeriksaan GGT

\begin{tabular}{cccc}
\hline Daerah & Nilai GGT normal & Nilai GGT tinggi & Total \\
\hline KelurahanTateli & 14 & 8 & 22 \\
KelurahanTelingAtas & 6 & 2 & 8 \\
Total & 20 & 10 & 30 \\
\hline
\end{tabular}

Tabel 2. Data deskriptif hasil penelitian

\begin{tabular}{cccccc}
\hline Data & N & Min & Max & Mean & SD \\
\hline Umur (tahun) & 30 & 22 & 40 & 30,93 & 4,291 \\
Skor AUDIT & 30 & 8 & 28 & 16,03 & 6,117 \\
GGT (U/L) & 30 & 15 & 275 & 68,13 & 66,038 \\
\hline
\end{tabular}


Conreng, Waleleng, Palar; Hubungan Konsumsi Alkohol dengan Gangguan Fungsi Hati...

Dari hasil analisis korelasi pearson antara skor AUDIT dan nilai GGT didapatkanhasil $\mathrm{r}=0,250$ dengan interpretasi adanya hubungan kecil $(\mathrm{r}=$ 0,20-0,29) antara kedua variabel, namun didapatkan hasil $\mathrm{p}=0,182(\mathrm{p}>0,05)$ dengan interpretasi tidak ada hubungan yang signifikan dari kedua variabel tersebut.

\section{BAHASAN}

Peningkatan GGT diatas nilai normal dapat menandakan berbagai masalah dan penyakit, namun yang terutama adalah gangguan fungsi hati, yaitu hepatitis atau sirosis. ${ }^{8,9}$ Sekitar 90\% peminum alkohol akan memiliki gangguan fungsi hati berupa perlemakan hati, namun hanya sekitar 10$30 \%$ peminum alkohol kronik yang akan mengalami hepatitis alkoholik. ${ }^{4}$

Hal tersebut sesuai dengan hasil pengumpulan data dari peneliti, dimana 10 orang (33,33\%) dari 30 orang yang dijadikan sampel memiliki nilai GGT tinggi yang menandakan adanya gangguan fungsi hati akibat konsumsi alkohol dalam jumlah yang besar dan pada waktu yang lama. Tapi didapatkan juga pada 5 dari 20 orang dengan nilai GGT normal memiliki skor AUDIT yang mendekati, bahkan melebihi nilai rata-rata skor AUDIT dari 10 orang yang memiliki nilai GGT tinggi. Hal ini menandakan adanya perbedaan efisiensi metabolisme alkohol pada hati antara kedua kelompok orang tersebut, dimana walaupun keduanya memiliki perikaraan jumlah konsumsi alkohol dan kebiasaan minum alkohol yang sama, 5 orang tersebut memiliki nilai GGT yang normal.

Namun, dari hasil pemeriksaan GGT saja belum pasti menandakan adanya gangguan fungsi hati, karena nilai GGT juga dapat meningkat pada peminum alkohol kronik tanpa adanya gangguan fungsi hati, sehingga harusnya perlu dilakukan pemeriksaan lanjut berupa biopsi hati untuk menentukan secara pasti derajat kerusakan pada hati pada sampel dengan nilai GGT tinggi. $6,7,9$

Perbandingan hasil korelasi antara skor AUDIT dan nilai GGT yang didapatkan oleh
Rotty L (2013) adalah adanya hubungan positif bermakna antara kedua variabel tersebut $(r=0,586$ dan $p=0,000)$ dengan jumlah sampel 40 orang yang diambil di kelurahan Kairagi II dan Wenang Utara kota Manado serta di desa Kalawat, Klabat dan Matungkas Kabupaten Minahasa Utara. ${ }^{10}$ Hal ini sesuai dengan penelitian oleh Bohn MJ, Babor TF dan Kranzler HR (1995) yang mendapat hubungan signifikan antara skor AUDIT dan nilai GGT dengan jumlah sampel 252 orang. ${ }^{11}$

Sehingga kuesioner AUDIT merupakan alat yang valid digunakan untuk mendeteksi adanya gangguan alkoholisme serta gangguan fungsi hati. Hal ini didukung oleh penelitian yang dilakukan oleh Conigrave KM, Saunders JB danReznik RB (1995) pada 250 orang denganskor AUDBT, dimana didapatkan $61 \%$ memiliki gangguan fungsi hati. ${ }^{12}$

\section{SIMPULAN}

Tidak semua peminum alkohol kronik akan mengalami hepatitis alkoholik atau bahkan sampai sirosis dalam jumlah konsumsi alkohol yang sama, namun sebagian besar pasti akan mengalami perlemakan hati.

\section{DAFTAR PUSTAKA}

1. Fleischmann A, Fuhr D, Poznyak V, Rekve D, Alwan A, Saraceno B et al. Global status report on alcohol and health. Geneva: World Health Organization; 2011.

2. Alcohol fact sheet [Internet]. 2011 February [citied 2013 October 1]. Available from: http://www.who.int/mediacentre/factsheets/fs 349/en/index.html

3. Korbanmiras di Indonesia mencapai 18.000 per tahun [Internet]. Jakarta: 2013 July 2 [citied 2013 September 24]. Available from: http://muslimdaily.net/berita/lokal/korbanmiras-di-indonesia-mencapai-18000-pertahun.html.

4. Longo DL, Kasper DL, Jameson JL, Faucy AS, Hauser SL, Loscalzo J. Harrison's principle of internal medicine. $18^{\text {th }} \mathrm{ed}$. New York: McGraw-Hill; 2011. Chapter 307, Alcoholic Liver Disease. 
5. Murphy SL, Xu J, Kochanek KD. Deaths: final data for 2010. Natl Vital Stat Rep. 2013 May 8;61(4):90.

6. Boon NA, Colledge NR, Walker BR. Davidson's principles and practices of medicine. 20 $0^{\text {th }}$ ed. London: Elsevier Health Sciences; 2006. Chapter 23, Liver and Billiary Track Disease; p.969-71.

7. Scharschmidt BF, Alpern RJ, Benz EJ, Char DH, Jacobs RA, Keeffe EB et al. Internal Medicine. New York: Cambridge University Press; 2007. p.89-92.

8. Longo DL, Kasper DL, Jameson JL, Faucy AS, Hauser SL, Loscalzo J. Harrison's principle of internal medicine. $18^{\text {th }}$ ed. New York: McGraw-Hill; 2011. Chapter 301, Approach to the Patient with Liver Disease.
9. McPherson RA, Pincus MR. Henry's clinical diagnosis and management by laboratory methods. $22^{\text {nd }}$ ed. Philadelphia: Elsevier Saunders;2011. p.304.

10. Rotty L. Hubunganskor AUDIT dengan tumor necrosis factor dan serum penandagangguanfungsihatipadalakilakidewasapeminumalkohol. 2013.

11. Bohn MJ, Babor TF, Kranzler HR. The alcohol use disorders identification test (AUDIT): validation of a screening instrument for use in medical settings. J Stud Alcohol. 1995;56:423-432.

12. Conigrave KM, Saunders JB, Reznik RB. Predictive capacity of the AUDIT questionnaire for alcohol-related harm. Addiction. 1995 Nov;90(11):1479-1485. 